\title{
The Effectiveness of Training and Mentoring Activities to Improve Cadre Performance in Child Growth Monitoring (CGM) by Martha Irene Kartasurya
}

Submission date: 13-Dec-2019 04:11PM (UTC+0700)

Submission ID: 1233782954

File name: 3.pdf (1.93M)

Word count: 3862

Character count: 20385 


\title{
The Effectiveness of Training and Mentoring Activities to Improve Cadre Performance in Child Growth Monitoring (CGM)
}

\author{
Suyatno ${ }^{1}$, Martha Irene Kartasurya ${ }^{1}$ \\ 'Department of Public Health Nutrition, Faculty of Public Health, Diponegoro University, Indonesia
}

\begin{abstract}
Routine growth monitoring of children in Indonesia is done through Posyan 1 . Posyandu cadres who have sufficient knowledge about Child Growth Monitoring (CGM) are needed to improve early detection of child malnutrition to prevent stunting. The ability to use WHO-Anthro software followed by mentoring programs is expected to help increase cadre capacity in CGM performance. This study aims to determine the effectiveness of training and mentoring a 1 livities in using WHO-Anthro software to improve cadres' performance in monitoring children's growth. This research was a collaborative research with the Ministry of Health. This experimental research used one group pretest-posttest design. This research was conducted on 30 female cadres 1 rom 30 Posyandu in Semarang City, Indonesia. Intervention activities and data collection were carried out for three months. Data were analyzed by comparison tests. The results showed that after the intervention there was an increase in knowledge scores, practice scores and performance scores of cadres in CGM. It was concluded that training and guidance on the implementation of WHO-Anthro software improved cadre performance in CGM.
\end{abstract}

Keywords: Posyandu cadre, child growth monitoring, WHO-Anthro, nutritional surveillance

\section{INTRODUCTION}

In Indonesia, child growth monitoring activities for early detection of growth disturbances are carried out through activities at Posyandu. The existence of Posyandu as an effort to early detection of community-based child growth disorders, was initially promoted by Unicef in the 1980 s with the aim of weighing children and heavy plots on growth charts for early detection of growth faltering, thus enabling community workers (cadres) to advise mothers about how to improve the growth of disturbed children ${ }^{1}$. The existence of Posyandu has been proven to play an important role in survival activities through growth monitoring and promotion activities (Growth Monitoring and Promotion) in children in Indonesia ${ }^{2.3}$. Like experience in many countries, child growth

\footnotetext{
Corresponding Author:

Suyatnoi

Department of Public Health Nutrition,

Faculty of Public Health, Diponegoro University, Indonesia Phone: +62 8212815730

Email: suyatnofkmundip@gmail.com
}

Monitoring and Promotion activities are supported by community participation through volunteer labor ${ }^{46}$.

However, there are a number of problems related to the implementation of Posyandu in child growth monitoring activities in Indonesia, among others: there are still inadequate facilities and skills of cadres', Posyandu cadres are volunteers, often change without being followed by training or retraining, as a result the technical abilities of active cadre are inadequate ${ }^{7}$, lack of ability which is very severe in weighing and plotting ${ }^{8}$, lack of ability of Posyandu cadres in conducting "nutritional counseling" causes nutritional education activities to become jammed or not implemented, so that toddlers who come are only weighed and recorded in Growth Monitoring Chart without adequate explanation so efforts to prevent the incidence of malnutrition are less effective ${ }^{7}$. Therefore, it is necessary to increase cadre capacity through ongoing training and mentoring activities $^{9.10}$ so that cadres have knowledge and selfefficacy cadres are increasing ${ }^{11.12}$ so that cadres become more confident in carrying out their tasks ${ }^{13}$, related to growth monitoring and providing nutrition counseling. 
Nutrition surveillance activities for early detection of nutritional problems in infants required strengthening of information systems in cadres. Strengthening of information subsystem in this matter was urgent so need to do the joint effort to push for all activity recording and data processing result of measurement of nutrition status gradually needed to be changed towards digital or computation.

Currently, the anthropometric index can be calculated using the World Health Organization's Child Growth Standard (WHO, 2007) using WHO-Anthro software. This application is simple enough to operate but is able to calculate anthropometry indicators and can present the data in the form of individual charts more accurately 9 Introducing the used of WHO-Anthro software to cadres expected to improve the 1 validity of weighing data processing Posyandu. Thus, this study aims to determine the effectiveness of training and mentoring activities in using WHO-Anthro software to improve cadres' performance in Child Growth Monitoring (CGM). The location of this study was Semarang City because the participation rate for Posyandu was $70.0 \%$ with the percentage of children under five coming and weighing $80.5 \%{ }^{8}$.

\section{MATERIAL AND METHOD}

Research Design and Study Subject: This research is an experimental study with the design of a pretest-posttest group without a con 1 l group with the nonrandom sample. The study was conducted on 30 female cadres from 30 Posyandu in health care Pudakpayung, Semarang City, Indonesia.

Data Collection: Data collection was carried out using a questionnaire consisting of seven parts. Part 1 is the characteristics of respondents consisting of 6 questions, including age, occupation, length of time as cadres, education, training history as cadres and frequency of cadre training. Section 2 is knowledge consisting of 37 questions, Part 3 is an attitude consisting of 29 questions. Section 4, practice consists of 29 questions. Section 5 is self-efficacy consisting of 30 questions. Section 6 is the cadre performance in Child Growth Monitoring (CGM), including (a) monitoring the nutritional status of children under five (2 questions), (b) data quality (7 questions), (c) data processing (5 questions), (d) cadre data analysis (3 questions), (e) program success (3 questions) and (f) achievement of cadre program targets (1 question).
The intervention consisted of training and mentoring the use of the Anthro WHO software for data management in Posyandu. Cadres are taught how to install Anthro WHO software and how to use the three main menus: (a) Anthropometric Calculator, b) Individual Assessment, and (c) Nutrition Survey, according to manual ${ }^{14}$. Then the trainer teaches the use of child growth monitoring charts. Intervention activities and data collection were carried out for three months. Data were collected twice (pretest and posttest), before and after the intervention.

\section{STATISTICAL ANALYSIS}

Data analysis was done with IBM SPSS Statistics. Research Method. Data distribution was tested using the Kolmogorov Smirnov test in which data is normally distributed if $\mathrm{p} \geq 0.05$. In answering the research objectives and proving the hypothesis, statistical tests were carried out using Mann Whitney, Wilcoxon and Rank Spearman tests.

\section{FINDINGS}

Characteristics of Respondents: Table 1 showed that most of the cadres were housewives who were not working $(80.0 \%)$. The education level of cadres was mostly highly educated (83.3\%). Two of the three cadres claimed to have attended the training twice. The average age of cadres was at 45.4 years with the average length of duty as a cadre for 10.1 years.

Impact of Intervention: The results showed an increase in the scores of cadre knowledge, attitudes, practices, self-efficacy and cadre performance in CGM (Table 2 ), but only scores of cadre knowledge, practice, and cadre performance in CGM were significantly different between before and after the intervention $(\mathrm{p}<0.05)$. A score of cadre attitudes and cadre self-efficacy did not differ significantly between before and after the intervention $(\mathrm{p} \geq 0.05)$.

Table 1: Characteristics of Respondents $(n=30)$

\begin{tabular}{|c|c|c|}
\hline Characteristics of Respondents & N & $\%$ \\
\hline Work Status \\
\hline Workers & 6 & 20,0 \\
\hline Not Workers & 24 & 80,0 \\
\hline Education Level & 5 & 16,7 \\
\hline Low & 5 & 83,3 \\
\hline High
\end{tabular}


Conted...

\begin{tabular}{|c|c|c|}
\hline \multicolumn{2}{|l|}{ Training History as Cadres } \\
\hline Never & 10 & 33,3 \\
\hline Ever & 20 & 66,7 \\
\hline And Frequency of Cadres Training \\
\hline Mean \pm S.D & $1,4 \pm 2,51$ \\
\hline Median (Min-Max) & $0,0(0,00-10,00)$ \\
\hline Age (Years) & $45,4 \pm 6,44$ \\
\hline Mean \pm S.D & $45,5(28,00-56,00)$ \\
\hline Median (Min-Max) & $10,1 \pm 9,31$ \\
\hline Length of Duty as Cadres & $6,5(1,00-35,00)$ \\
\hline Mean \pm S.D &
\end{tabular}

Factors related to changes in cadre performance: The relationship between personal characteristics of cadres and changes in knowledge, attitudes, practices, self-efficacy and CGM performance scores are presented in Table 3. Based on Table 3, the cadre's personal characteristics are significantly related to changes in knowledge scores are the level of education of cadres and history have attended cadre training, while those related to change 1 in attitude scores are the status of cadre work, and related to changes in practice scores are the frequency of cadre training. However, no cadre personal characteristics were significantly associated with changes in self-efficacy scores. The personal characteristics of cadres significantly related to changes in CGM performance scores are cadre work status.

Table 4 shows the results of correlation analysis between various variables, including changes in knowledge score, attitude scores, practice scores, selfefficacy scores, and CGM performance scores. The results showed a positive correlation between changes in knowledge scores and changes in practice scores $(\mathrm{r}=0.407 ; \mathrm{p}=0.026)$. While there is no significant correlation between the other variables (Table 4)

\section{DISCUSSION}

The skills of cadres in the management of anthropometric measurement data can be increased by providing training in accordance with procedures. During this time cadres have received basic training and refresher on service activities in Posyandu with conventional approaches, namely training with lecture methods, accompanied by discussions with trainers. One of the weaknesses of the conventional method is that it only increases knowledge, but does not improve the skills of trainees. The method used in training should be adapted to the problems, situations, and conditions of the trainees so that the skills and performance of Posyandu cadres can increase ${ }^{15}$.

Table 2: Comparation of pretest and posttest score $(n=30)$

\begin{tabular}{|c|c|c|c|c|c|}
\hline Variable & Pretest Score & Posttest Score & $\Delta$ (Score Change) & Percentage of $\Delta(\%)$ & p \\
\hline \multicolumn{6}{|l|}{ Knowledge } \\
\hline Mean \pm S.D & $64,1 \pm 2,88$ & $64,7 \pm 3,62$ & $2,4 \pm 2,71$ & $4,0 \pm 4,56$ & \multirow{2}{*}{$0,001^{\mathrm{a}}$} \\
\hline Median (Min-Max) & $64,0(58,00-70,00)$ & $66,0(56,00-70,00)$ & $2,0(-2,00-10,00)$ & $3,2(-2,94-17,86)$ & \\
\hline \multicolumn{6}{|l|}{ Attitude } \\
\hline Mean \pm S.D & $54,2 \pm 2,34$ & $54,7 \pm 3,16$ & $1,2 \pm 1,74$ & $2,4 \pm 3,30$ & \multirow{2}{*}{$0,131^{b}$} \\
\hline Median (Min-Max) & $54,5(49,00-57,00)$ & $56,0(44,00-58,00)$ & $2,0(-2,00-5,00)$ & $1,8(-3,57-9,80)$ & \\
\hline \multicolumn{6}{|l|}{ Practice } \\
\hline Mean \pm S.D & $52,2 \pm 3,62$ & $53,5 \pm 3,57$ & $1,6 \pm 3,31$ & $4,7 \pm 6,57$ & \multirow{2}{*}{$0,048^{\mathrm{b}}$} \\
\hline Median (Min-Max) & $52,5(43,00-58,00)$ & $55,0(45,00-58,00)$ & $2,0(-3,00-12,00)$ & $3,2(-7,14-20,42)$ & \\
\hline \multicolumn{6}{|l|}{ Self Efficacy } \\
\hline Mean \pm S.D & $65,0 \pm 15,02$ & $64,81 \pm 22,04$ & $7,7 \pm 9,97$ & $14,6 \pm 19,22$ & \multirow{2}{*}{$0,614^{b}$} \\
\hline Median (Min-Max) & $64,9(38,83-90,33)$ & $69,8(0,00-90,33)$ & $6,8(-17,00-31,66)$ & $8,8(-20,65-70,88)$ & \\
\hline \multicolumn{6}{|c|}{ CGM Performance } \\
\hline Mean \pm S.D & $4,4 \pm 1,37$ & $3,6 \pm 3,85$ & $0,7 \pm 1,48$ & $0,5 \pm 0,74$ & \multirow{2}{*}{$0,007^{\mathrm{b}}$} \\
\hline Median (Min-Max) & $4,9(0,47-5,96)$ & $3,8(0,0-4,77)$ & $0,6(-3,30-2,79)$ & $0,17(-3,30-1,0)$ & \\
\hline & & Paired T-Test, ${ }^{\mathrm{b}} \mathrm{Wi}$ & xon Test & & \\
\hline
\end{tabular}


Table 3: The relationship between individual cadre characteristics and change of cadre performance score (score gain) after intervention

\begin{tabular}{|c|c|c|c|c|c|}
\hline Variable & $\begin{array}{c}\Delta \text { Knowledge } \\
\text { score }\end{array}$ & $\begin{array}{l}\Delta \text { Attitude } \\
\text { score }\end{array}$ & $\begin{array}{c}\Delta \text { Practice } \\
\text { score }\end{array}$ & $\begin{array}{c}\Delta \text { Self } \\
\text { Efficacy } \\
\text { score }\end{array}$ & $\begin{array}{c}\Delta \text { CGM } \\
\text { Performance } \\
\text { score }\end{array}$ \\
\hline Employment Status & $30,374^{b}$ & $0,044^{\mathrm{c}}$ & $0,462^{b}$ & $0,416^{\mathrm{c}}$ & $0,041^{\mathrm{c}}$ \\
\hline Age (Year) & $\begin{array}{l}\mathrm{r}=0,090 \\
\mathrm{p}=0,337^{\mathrm{d}}\end{array}$ & $\begin{array}{l}\mathrm{r}=0,022 \\
\mathrm{p}=0,910^{\mathrm{c}}\end{array}$ & $\begin{array}{l}\mathrm{r}=-0,070 \\
\mathrm{p}=0,411^{\mathrm{d}}\end{array}$ & $\begin{array}{l}\mathrm{r}=0,085 \\
\mathrm{p}=0,657^{\circ}\end{array}$ & $\begin{array}{l}\mathrm{r}=0,002 \\
\mathrm{p}=0,991^{\mathrm{e}}\end{array}$ \\
\hline Education Level & $3_{3}, 022^{b}$ & $0,463^{\mathrm{c}}$ & $0,208^{\mathrm{b}}$ & $0,496^{\mathrm{c}}$ & $0,538^{\mathrm{c}}$ \\
\hline Long Being a Cadre & $\begin{array}{l}\mathrm{r}=-0,124 \\
\mathrm{p}=0,512^{\mathrm{d}}\end{array}$ & $\begin{array}{l}\mathrm{r}=0,022 \\
\mathrm{p}=0,910^{\mathrm{e}}\end{array}$ & $\begin{array}{l}\mathrm{r}=-0,260 \\
\mathrm{p}=0,166^{\mathrm{d}}\end{array}$ & $\begin{array}{l}\mathrm{r}=0,160 \\
\mathrm{p}=0,398^{\mathrm{e}}\end{array}$ & $\begin{array}{l}\mathrm{r}=0,255 \\
\mathrm{p}=0,173^{\mathrm{e}}\end{array}$ \\
\hline History Following Cadre Training & $3_{3}^{0,013^{\mathrm{b}}}$ & $0,424^{\mathrm{c}}$ & $0,559^{b}$ & $0,617^{\mathrm{c}}$ & $0,609^{\mathrm{c}}$ \\
\hline Frequency of Cadre Training & $\begin{array}{l}r=-0,164 \\
p=0,385^{d}\end{array}$ & $\begin{array}{l}\mathrm{r}=0,246 \\
\mathrm{p}=0,190^{\mathrm{e}}\end{array}$ & $\begin{array}{l}r=0,350 \\
p=0,038^{d}\end{array}$ & $\begin{array}{l}r=-0,021 \\
p=0,914^{e}\end{array}$ & $\begin{array}{l}r=0,126 \\
\mathrm{p}=0,507^{\mathrm{e}}\end{array}$ \\
\hline
\end{tabular}

Table 4: Correlation (r) among change of knowledge, attitude, practice, self-efficacy, and CGM performance score

\begin{tabular}{|c|c|c|c|c|c|c|}
\hline & & $\begin{array}{l}\Delta \text { Knowledge } \\
\text { score }\end{array}$ & $\begin{array}{l}\Delta \text { Attitude } \\
\text { score }\end{array}$ & $\begin{array}{c}\Delta \text { Practice } \\
\text { score }\end{array}$ & $\begin{array}{c}\Delta \text { Self } \\
\text { Efficacy score }\end{array}$ & $\begin{array}{c}\Delta \mathrm{CGM} \\
\text { Performance score }\end{array}$ \\
\hline \multirow{2}{*}{$\Delta$ Knowledge score } & $\mathrm{r}$ & & -0.021 & 0.407 & -0.094 & -0.085 \\
\hline & (p) & & $(0.911)$ & $(0.026)$ & $(0.622)$ & $(0.655)$ \\
\hline \multirow{2}{*}{$\Delta$ Attitude score } & $\mathrm{r}$ & & & 0.234 & 0.253 & -0.090 \\
\hline & (p) & & & $(0.214)$ & $(0.177)$ & $(0.636)$ \\
\hline \multirow{2}{*}{$\Delta$ Pactice score } & $\mathrm{r}$ & & & & -0.063 & 0.159 \\
\hline & (p) & & & & $(0.742)$ & $(0.401)$ \\
\hline \multirow{2}{*}{$\Delta$ Self Efficacy score } & $\mathrm{r}$ & & & & & -0.131 \\
\hline & (p) & & & & & $(0.491)$ \\
\hline \multirow{2}{*}{$\begin{array}{l}\Delta \text { CGM Performance } \\
\text { score }\end{array}$} & $\mathrm{r}$ & & & & & \\
\hline & (p) & & & & & \\
\hline
\end{tabular}

This study proves that training is followed by mentoring on the use of WHO-Anthro software in CGM activities affected changes in cadre knowledge scores, practices, and cadre performance. It proves that with the accompaniment of continuously, knowledge of cadres would be increased. With increasing knowledge, it would also improve the ability of practice. As practice was a manifestation of an action based on the previous empowerment. With the increased practice score, then indirectly would also increase the performance of cadres Posyandu. Thus, cadres could perform the tasks in accordance with the objectives to be achieved from the implementation of Posyandu ${ }^{16}$. In the indicator of data quality and the achievement of program facilities in performance surveillance variable did not change the score of the possibility occurred because the cadres were actually experiencing confusion data processing through the computerized system with WHO-Anthro. After being assisted, the cadres learned more about Posyandu and WHO-Anthro so they realized that facilities in their Posyandu still lacking ${ }^{17}$.

The impact of the training on improving the skills of Posyandu cadres has been widely demonstrated, that the skills of Posyandu cadres in anthropometric measurements increase after participating in training ${ }^{18,19}$.

The results of this study are similar to the findings of the study in the city of Banda Aceh ${ }^{18}$, which found the quality of information on training groups based on WHO-Anthro software after one month of training had a good improvement, especially in terms of timely, completeness, and accuracy aspects. After one month of training and the application of WHO growth standards in the treatment group based on WHO-Anthro software 
showed an increase in the percentage of information quality of nutritional status data on children under five reaching $13.6 \%$. The quality of nutritional data from trainees based on WHO-Anthro software had better effectiveness than manual-based training. This finding is reinforced by De Onis et al., The use of WHO-Anthro software can accelerate the process and increase the validity of input-output data produced, and become an important part in the assessment or monitoring of nutritional status ${ }^{20}$.

The impact of interventions on changes in cadre performance at CGM was higher found in cadres with working status than those who did not work. The cadres who work are thought to be better able to adapt and implement new applications because they have better working skills. The intervention on changes in knowledge and practice was found to be higher in cadres who previously had a history of training or more training frequency. Previous training that has been accumulated will increase more trained knowledge, insight, and skills. The link between training increased knowledge and skills has been found through this study, that changes in knowledge are positively correlated with changes in cadre practices.

In this study, training did not significantly affect changes in self-efficacy variables, and a number of characteristics of cadre characteristics were also not related to changes in self-efficacy scores. However, self-efficacy scores have proven to increase after training and mentoring. this may occur because the activity is not focused on how to improve good self-efficacy because if this process is carried out it will take longer and not less cost. Factors such as mastery experiences, vicarious experiences, social persuasion, physiological and emotional states ${ }^{21}$ have not been included in the analysis. The results of this study are different from the results of research conducted on Posyandu cadres in East Java, where interventions can significantly improve self-efficacy and affective abilities ${ }^{22}$. The higher self-efficacy will have a positive effect on improving the affective ability of a cadre, and the higher the affective ability of a cadre will have an effect on increasing healthy behavior $^{23}$. Increased cadre ability will have an impact on Posyandu management, especially growth monitoring and health promotion.

Training activities on the implementation of WHOAnthro software have been proven to improve Posyandu cadre knowledge, but to improve the practice and cadre performance need three months of assistance. This research completed evidence, that to change the pact and ability of cadres could not be done in a short time, but needed assistance. Intervention with the training model alone is not enough, it needs to be continued with field assistance that is carried out on-going.

Although training and mentoring on the use of WHO-Anthro software have been proven to be able to improve the knowledge, practice, and performance of Posyandu cadres, the intervention model has not been able to address all the issues related to cadres in the Posyandu. The cadres often change and need to be followed by training or retraining so that the technical skills of active cadre nutrition are adequate and have the ability to do "nutrition counseling and counseling" so that nutritional education activity can be run ${ }^{7}$.

\section{CONCLUSION}

It was concluded that training and guidance on WHO-Anthro software implementation improve cadres performance and nutrition surveillance in Posyandu. To improve the capacity of cadre in handling the Posyandu information system, it is necessary to train and carried out the mentoring activities (in at least three months).

Conflict of Interest: The authors declare that there was no conflict of interest.

Source of Funding: The research was funded by the Directorate of Community Nutrition, the Indonesian Ministry of Health

Ethical Clearance: This study was approved by the Ethics Committee for Health Research at the Faculty of Public Health, Diponegoro University, Indonesia

\section{REFERENCES}

1. MOH-Pokjanal. General guidelines for posyandu management. Jakarta; 2011.

2. Anwar F, Khomsan A, Sukandar D, Riyadi $\mathrm{H}$, Mudjajanto ES. High participation in the Posyandu nutrition program improved children nutritional status. Nutr Res Pract. 2010. https:// doi.org/10.4162/nrp.2010.4.3.208

3. Leimena SL. Posyandu: a community based vehicle to improve child survival and 


\section{Indian Journal of Public Health Research \& Development, March 2019, Vol.10, No. 3}

development. Asia-Pacific Journal of Public Health. 1989;3(4), 264-267. https://doi. org/10.1177/101053958900300402

4. Ma Y, Kim H, Cho Y, et al. Effects of community health volunteers on infectious diseases of children under five in Volta Region, Ghana: study protocol for a cluster randomized controlled trial. BMC Public Health. 2017;(17):95 https://doi. org/10.1186/s12889-016-3991-z

5. Yadav DK, Gupta N, Shrestha N, Kumar A, Bose DK. Community-based nutrition education for promoting the nutritional status of children under three years of age in rural areas of Mahottari District of Nepal. J Nepal Paediatr Soc. 2014. https://doi.org/10.3126/jnps.v34i3.10286

6. Faber M, Phungula MAS, Kvalsvig JD, Benadé AJS. Acceptability of communitybased growth monitoring in a rural village in South Africa. Food Nutr Bull. 2003. https://doi. org/10.1177/156482650302400405.

7. Kalsum U, Jahari AB. The strategy to reduce the prevalence of malnutrition among children under five in Jambi Province. JMJ. 2015;3(1):45-59. Available online: https://media.neliti.com/media/ publications/71185-ID-strategi-menurunkanprevalensi-gizi-kura.pdf

8. DixonRA.Cost-effectivenessofgrowthmonitoring and promotion. Lancet. 1993;342(8867):317. https://doi.org/10.1016/0140-6736(93)91465-X.

9. WHO. Guidelines for training community: health workers in nutrition; 1981. Available online: http://pesquisa.bvsalud.org/bvsms/resource/pt/ mis-17660.

10. Zaman S, Ashraf RN, Martines J. Training in complementary feeding counseling of healthcare workers and its influence on maternal behaviors and child growth: a cluster-randomized controlled trial in Lahore, Pakistan. J Heal Popul NUTR. 2008;26(2):210-222. Available online: https://www.ncbi.nlm.nih.gov/pmc/articles/ PMC2740673/

11. Martocchio JJ. Effects of conceptions of ability on anxiety, self-efficacy, and learning in training. J Appl Psychol. 1994;79(6):819-825.
12. Shirazi KK, Niknami S, Wallace L, Hidarnia A, Rahimi E, Faghihzadeh S. Changes in self-efficacy and decisional balance following an intervention to increase consumption of calcium-rich foods. Soc Behav Personal an Int J. 2006. https://doi. org/10.2224/sbp.2006.34.8.1007.

13. Judge TA, Bono JE. Relationship of core selfevaluations traits - self-esteem, generalized self-efficacy, the locus of control, and emotional stability - With job satisfaction and job performance: A meta-analysis. J Appl Psychol. 2001;86(1):80-92. https://doi.org/10.1037//00219010.86 .1 .80

14. WHO. WHO-Anthro for personal computers manual, software for assessing growth and development of the world's children. WHO, Dep Nutr Heal Dev Geneva. 2011. Available online: https://www.who.int/childgrowth/software/ anthro_pc_manual_v322.pdf.

15. Sukiarko E. Effect of training with learning methods based on problems with knowledge and skills of nutrition cadres in Posyandu activities study in Tempuran Subdistrict, Magelang Regency. Diponegoro University. Semarang:2007. Available online: http://eprints.undip.ac.id/15497/

16. Sengkey S, Kandou G, Pangemanan JM. Performance analysis of cadres Posyandu in Puskesmas Paniki Manado. JIKMU. 2015;5(2b):491-201. Available online:https:// ejournal.unsrat.ac.id/index.php/jikmu/article/ download/7858/7908

17. Saepudin E, Rizal E, Rusman A. Roles as mothers and children health information center. Rec Libr J. 2017;3(2). Available online: https://e-journal. unair.ac.id/RLJ/article/viewFile/7338/4439

18. Rahmad AH. The effectiveness of WHO-Anthro growth standard training on the quality of nutritional status data for children under five. Journal of Information Systems for Public Health. 2016;1(1):39-46. Available online: https://journal. ugm.ac.id/jisph/article/view/6095

19. Fitri HM, Mardiana. Training toward skill of Posyandu cadres. Kemas. 2011;7(1):22-27. Available online: http://journal.unnes.ac.id/index. php/kemas. 
20. De Onis M, Garza C, Onyango AW, Borghi E. Comparison of the who child growth standards and the CDC 2000 growth charts. JNutr. 2007; 137:144148. https://doi.org/137/1/144 [pii].

21. Bandura A. Self-efficacy: the exercise of ccontrol. Am J os Heal Promot. 1997;149(3):8-10. doi: $10.1177 / 0957154 X 9400501708$.

22. Pratiwi NL, Pradopo S. Effect of self-efficacy on improving affective ability of health cadres and impact on healthy behavior of teeth through detection model of OHI-S, DMFT Index. Bul Penelit Sist Kesehat. 2006;9(1):51-60.

23. Baranowski. Cheryl IP, Guy S Parcel. How Individual, Environment, and Health Behavior Interact, Social Cognitive Theory in Text Book Health Behavior and Health Education, Editor: Karen Glanz, Frances M L. Barbara K Rimer. 2nd Edition by Jossey-Bass Inc.; 1997.

24. Bandura A. Encyclopedia of Mental Health. Vol 4. Academic Press; 1994. 


\section{The Effectiveness of Training and Mentoring Activities to Improve Cadre Performance in Child Growth Monitoring (CGM)}

ORIGINALITY REPORT

$11 \%$

SIMILARITY INDEX
$7 \%$

INTERNET SOURCES
$5 \%$

PUBLICATIONS
$8 \%$

STUDENT PAPERS

PRIMARY SOURCES

1

Submitted to Universitas Diponegoro

Student Paper

2 media.neliti.com

Exclude quotes

Off

Exclude bibliography

Off
Exclude matches

$<2 \%$ 